\title{
The antibiotic puzzle: Guidelines for the family physician
}

G Harding, S Field, R MacMahon, T Louie and the Prairie Consensus Conference Group. The antibiotic puzzle: Guidelines for the family physician. Can J Infect Dis 1997;8(Suppl C):2C-16C. Choosing the most appropriate antibiotic for the treatment of common infections is becoming increasingly complex. New drugs and new classes of antibiotics are being developed and made available, and emerging resistance and pharmacoeconomics play important roles. The Canadian healthcare system presents a unique challenge for prescribing physicians because pharmacoeconomic considerations are becoming increasingly important. It is important that Canadian guidelines be developed to address the needs of Canadian physicians. A consensus conference was held in October 1996 to discuss appropriate guidelines for antibiotic recommendations for common adult respiratory, urinary tract and diabetic foot infections. In August 1997, the guidelines were reviewed and updated as part of a second meeting of the group on antimicrobial resistance. The final recommendations constitute the information in this document. The panel of physicians and pharmaceutical doctors from the Prairie provinces of Alberta, Saskatchewan and Manitoba included family physicians and specialists in internal medicine, respirology, urology, infectious diseases, medical microbiology and pharmacoeconomics.

Key Words: Antibiotic guidelines, Diabetic foot infections, Family physician, Infection guidelines, Prostatitis, Respiratory tract infections, Urinary tract infections

\section{Le casse-tête de l'antibiothérapie Directives à l'intention du médecin de famille}

RÉSUMÉ : Le choix de l'antibiotique le plus approprié pour le traitement des affections courantes devient de plus en plus complexe. De nouveaux médicaments et de nouvelles classes d'antibiotiques font constamment leur apparition sur le marché, sans compter que l'émergence des souches résistantes et que la pharmacoéconomie jouent aussi un rôle prépondérant. Le système canadien de soins de santé pose un défi unique aux médecins de premier recours à cause de l'importance croissante accordée aux principes de pharmacoéconomie. Il est important de mettre au point des directives qui puissent répondre spécifiquement aux besoins des médecins canadiens. Une conférence consensuelle a eu lieu en octobre 1996; on y a discuté des directives relatives à l'antibiothérapie appliquée aux infections respiratoires et urinaires courantes de l'adulte, ainsi qu'aux infections du pied chez le diabétique. En août 1997, les directives ont été passées en revue et mises à jour dans le cadre d'une seconde rencontre du groupe formé pour traiter de la résistance aux antimicrobiens. Les recommandations finales forment l'essentiel du présent document. Un comité de médecins et de pharmacologues des provinces de l'Ouest (Alberta, Saskatchewan et Manitoba) été formé et regroupait des médecins de familles, des internistes, des pneumologues, des urologues, des infectiologues, des microbiologistes et des spécialistes de la pharmacoéconomie. 
$\mathrm{C}$ hoosing the most appropriate antibiotic for the treatment of common infections is becoming increasingly complex. New drugs and new classes of antibiotics are being developed and made available, emerging resistance is still a factor and pharmacoeconomics plays a very important role. In addition, at times, standard first-line treatment may not be appropriate, especially when the risk and consequences of treatment failure are particularly high.

The plan: With changing resistance profiles, regional microbiological prevalence differences and the availability of new anti-infective agents, therapeutic guidelines must be reviewed regularly and updated. It is important that Canadian guidelines be developed to address the needs of Canadian physicians. The need for practical guidelines for family physicians was identified.

The Canadian healthcare system presents a unique challenge for prescribing physicians because pharmacoeconomic considerations are becoming increasingly important. It is no longer acceptable to look at the cost of a drug alone. Cost analysis should consider indirect costs such as those associated with adverse effects, time lost from work and treatment failure, and intangible costs such as the cost of a life saved. In some instances the higher cost of second-line antibiotics can be justified if treatment is expected to reduce the risk of deterioration, which may result in hospitalization. Thus, where appropriate, pharmacoeconomics should be considered when making therapeutic recommendations.

The panel: In October 1996, Dr Godfrey Harding brought together a panel of physicians and pharmaceutical doctors from the Prairie provinces of Alberta, Saskatchewan and Manitoba for a consensus conference to discuss appropriate guidelines for antibiotic recommendations for common adult respiratory, urinary tract and diabetic

TABLE 1

First-line antibiotic treatment for acute sinusitis

Grade D recommendations

\begin{tabular}{ll} 
Antibiotic & Dose \\
\hline Co-trimoxazole & $\begin{array}{l}\text { 160/800 mg bid for seven to } 10 \text { days } \\
\text { Doxycycline }\end{array}$ \\
$\begin{array}{r}200 \mathrm{mg} \text { first day, then } 100 \mathrm{mg} \text { once } \\
\text { daily for seven to } 10 \text { days }\end{array}$ \\
Amoxicillin & 250 to $500 \mathrm{mg}$ tid for seven to 10 days \\
\hline
\end{tabular}

If a course of first-line treatment fails, a second course with a different first-line antibiotic should be tried. Second-line antibiotics are indicated when first-line antibiotics have failed or there is a history of recent first-line failure foot infections. The panel included family physicians and specialists in internal medicine, respirology, urology, infectious diseases, medical microbiology and pharmacoeconomics. The panel's mandate was to develop practical, current antibiotic treatment guidelines that would be useful to a family physician in everyday practice.

Team leaders (chairs) were identified before the workshop and included Drs Stephen Field, Ross MacMahon and Thomas Louie. After reviewing the pertinent literature, they developed working documents with references, which were handed out before the plenary sessions. The working documents with proposed recommendations were presented at a plenary session before the entire group for discussion. In addition, Dr George Zhanel gave a talk on pharmacoeconomic issues pertinent to these topic areas. The next day, the team leaders chaired small group breakout sessions on their respective topic areas, and the recommendations were revised. These recommendations were presented to the entire group and agreed upon at a second plenary session. In August 1997, the proposed guidelines were reviewed and updated as part of a second meeting of the group on antimicrobial resistance. The final recommendations, which constitute the information in this document, were agreed upon at the final plenary session

\section{TABLE 2}

Second-line antibiotic treatment for acute sinusitis

Grade D recommendations

Antibiotic Dose

Amoxicillin/

$250 / 125$ to $500 / 125 \mathrm{mg}$ tid for 10

clavulanate

to 14 days

Clarithromycin

$500 \mathrm{mg}$ bid for 10 to 14 days

Azithromycin

$500 \mathrm{mg}$ first day, then $250 \mathrm{mg}$ for four days

Ciprofloxacin

$500 \mathrm{mg}$ bid for 10 to 14 days

Ofloxacin

$400 \mathrm{mg}$ bid for 10 to 14 days

Cefaclor

250 to $500 \mathrm{mg}$ tid for 10 to 14 days

Cefuroxime axetil $\quad 250$ to $500 \mathrm{mg}$ bid for 10 to 14 days

Cefixime $400 \mathrm{mg}$ once daily for 10 to 14 days

If second-line treatment fails, refer patient to specialist. Other reasons to consider referral are recurrent disease (greater than three episodes per year) and the development of complications such as mucoceles or orbital extension 
TABLE 3

Group 1 - Acute bronchitis: Previously healthy patients with no other respiratory problems or comorbidity

\begin{tabular}{|c|c|c|}
\hline $\begin{array}{l}\text { Grade } D \text { recommendations } \\
\text { Considerations }\end{array}$ & Antibiotic & Dose and duration \\
\hline & No treatment or erythromycin* & $1 \mathrm{~g} /$ day in divided doses for 10 to 14 days \\
\hline If macrolide allergy & Doxycycline & $\begin{array}{l}200 \mathrm{mg} \text { first day, then } 100 \mathrm{mg} \text { once daily for } \\
\text { nine days }\end{array}$ \\
\hline $\begin{array}{l}\text { If gastrointestinal intolerance to } \\
\text { erythromycin or }\end{array}$ & Azithromycin or & $\begin{array}{l}500 \mathrm{mg} \text { first day, then } 250 \mathrm{mg} \text { once daily for } \\
\text { four days }\end{array}$ \\
\hline if smoker with possible Hemophilus influenzae & clarithromycin & 250 to $500 \mathrm{mg}$ bid for 10 days \\
\hline
\end{tabular}

*If purulent sputum and/or fever is present, the physician may consider prescribing an antibiotic. Amoxicillin, second generation cephalosporins or amoxicillin/clavulanate were not recommended because they fail to provide coverage for Mycoplasma pneumoniae and Chlamydia pneumoniae.

\section{TABLE 4}

Group 2 - Exacerbations of simple chronic bronchitis: Patients less than 65 years of age, forced expiratory volume in $1 \mathrm{~s}$ less than $50 \%$ predicted, less than four exacerbations per year and no comorbidity

Grade A recommendations

Considerations

Type 3

Type 1 or Type 2
Antibiotic

No antibiotic required

Co-trimoxazole or

doxycycline or

amoxicillin
Dose and duration

160/800 mg bid for 10 days

$200 \mathrm{mg}$ first day, then $100 \mathrm{mg}$ once daily for nine days

250 to $500 \mathrm{mg}$ tid for 10 days chaired by Dr Harding after the breakout sessions. The antibiotic recommendations are for average-sized adults with normal renal function.

\section{USE OF ANTIBIOTICS IN RESPIRATORY TRACT INFECTIONS}

The etiological organisms involved in a respiratory tract infection are usually unknown when therapy is initiated, and an antibiotic must be chosen without the benefit of microbiological diagnosis. It may be difficult to confirm a diagnosis because of previous antibiotic therapy, normal flora or the presence of other contaminating potential pathogens in culture specimens. Antibiotic selection is based on the spectrum of pathogens usually seen in a particular setting.

Acute sinusitis: Seventy per cent of bacterial isolates found in adults and children with acute sinusitis are Streptococcus pneumoniae and Hemophilus influenzae (1). Nasal swab results do not correlate well with antral cultures, and such swabs are not recommended for culture.
Decongestants and analgesics are helpful in acute sinusitis, but nasal decongestants should not be given for more than five days to prevent rebound vasodilation. Antihistamines should be avoided because their anticholinergic effect can interfere with normal mucociliary clearance (1).

Although $40 \%$ of cases of acute sinusitis resolve spontaneously, a therapeutic advantage to antibiotic therapy was demonstrated in some but not all studies (1-4). Tables 1 and 2 reflect the consensus agreement by the panel, with the caveat that local resistance profiles be considered when choosing therapy. Recent microbiological sensitivity surveys have shown a rising prevalence of penicillin-resistant $S$ pneumoniae and beta-lactamase-producing $H$ influenzae, which may be as high as $40 \%$ (5). In view of the steady rise of antibiotic resistance, amoxicillin may not remain a first-line antibiotic choice in the future.

Chronic sinusitis: Chronic sinusitis is usually the result of ostial obstruction due to allergy, deviated septum or nasal polyps. Topical steroids and antihistamines may 
TABLE 5

Group 3 and 4 - Exacerbations of complicated chronic bronchitis: Patients with four or more exacerbations per year, forced expiratory volume in $1 \mathrm{~s}$ less than $50 \%$ predicted, older than 65 years of age or comorbidity

Grade D recommendations

Considerations

Antibiotic

Dose and duration

The use of second-line antibiotics may be justified to minimize treatment failure

\begin{tabular}{|c|c|}
\hline Azithromycin or & $500 \mathrm{mg}$ first day, $250 \mathrm{mg}$ once daily for four days \\
\hline clarithromycin or & $500 \mathrm{mg}$ bid for 10 to 14 days \\
\hline ciprofloxacin or & $500 \mathrm{mg}$ bid for 10 to 14 days \\
\hline ofloxacin or & $400 \mathrm{mg}$ bid for 10 to 14 days \\
\hline cefaclor or & $500 \mathrm{mg}$ tid for 10 to 14 days \\
\hline cefuroxime axetil or & $500 \mathrm{mg}$ bid for 10 to 14 days \\
\hline cefixime & $400 \mathrm{mg}$ once daily for 10 to 14 days \\
\hline
\end{tabular}

Treatment failure suggests inflammation rather than bacterial infection. Consider sputum Gram stain and culture, and referral to a specialist

be beneficial. If infection is present, a prolonged course of antibiotics for two to four weeks may be required.

Opportunistic organisms that can grow in obstructed sinuses include the anaerobes $H$ influenzae and $S$ aureus. Amoxicillin/clavulanate is effective against most anaerobes. Pseudomonas aeruginosa may be found if polyps are present and may be treated with ciprofloxacin.

Referral to a specialist is recommended for most patients. Surgery may be necessary if medical therapy is unsuccessful.

\section{Recommendation for treatment of chronic sinusitis \\ - Topical steroids and antihistamines \\ - Prolonged antibiotic therapy for bacterial infection \\ - Referral if medical treatment is unsuccessful}

Acute exacerbations of chronic bronchitis: Measures to prevent acute exacerbation of chronic bronchitis include smoking cessation, vaccination against influenza and, in selected cases, vaccination against $S$ pneumoniae. Exacerbations can be precipitated by a variety of triggers, both infectious and noninfectious. Patients should be advised to avoid irritants such as cigarette smoke during an exacerbation. Exacerbations should be treated with bronchodilators, corticosteroids, supplemental oxygen if the patient is hypoxemic and antibiotics.

\section{Recommendations for treatment of acute exacerbations of chronic bronchitis \\ - Bronchodilators \\ - Corticosteroids \\ - Supplemental oxygen \\ - Antibiotics}

Canadian guidelines for the management of chronic bronchitis were published in 1994 (6). These recommendations stratified patients into five groups on the basis of severity of disease, partly defined by the forced expiratory volume in $1 \mathrm{~s}$, number of exacerbations per year and presence of comorbidity. The panel adopted the guidelines mentioned above and agreed with the antibiotic choices detailed there, which were based on the likelihood of bacterial infection in a particular setting, risk of treatment failure and pharmacoeconomic considerations (Tables 3-5). In addition, the panel felt that the stratification system for exacerbations developed by Anthonisen et al (7) was helpful. Type 1 exacerbations are characterized by increased dyspnea, increased sputum volume and purulence. Type 2 exacerbations are characterized by two of the above three symptoms. Type 3 exacerbations are characterized by one of the three symptoms and one other finding of fever, sore throat, nasal discharge, wheeze or cough. The efficacy of antibiotic therapy for Type 1 exacerbations of chronic bronchitis is well documented (7). 
In general, treatment failure suggests inflammation rather than infection, and the panel recommended sputum Gram stain and culture, and referral to a specialist for such cases.

Group 5 - Bronchiectasis: Bronchiectasis is characterized by recurrent infections and ongoing sputum purulence. The panel recommended that patients in this group be referred for investigation and treatment. Patients should receive antibiotics tailored to the specific pathogens and the susceptibility of the pathogens found in the patient's sputum culture.

Community-acquired pneumonia: Most patients with community-acquired pneumonia (CAP) can be managed as out-patients; however, CAP severe enough to warrant hospitalization has a mortality rate that may exceed $20 \%$ (8). Mortality is dependent on the extent of lung involvement, age, comorbidity and the need for mechanical ventilation. In nursing homes, the mortality rate may be as high as $40 \%$ (9).

For the majority of patients (Table 6), diagnostic information on the etiological agent is not available until several days after presentation. In most cases, sputum cultures are inconclusive, and it may be impossible to distinguish colonizing organisms from invasive organisms. Chest radiograph is often unhelpful in distinguishing among the common etiological causes of CAP (10). Although microbiological evidence is preferred, the selection of an antibiotic is often made on the basis of epidemiological data, and clinical presentation and findings.

The Canadian Conference Group on CommunityAcquired Pneumonia stratified CAP patients into four groups based on severity of illness, setting in which pneumonia developed, age, comorbidity and need for hospitalization (8). The recommendations presented here (Table 7) are based on their guidelines; local modification may be necessary to account for varying organism prevalence or antibiotic resistance profiles. These recommendations assume that documented evidence of pneumonia will be available during the course of treatment.

The panel also felt that nursing home patients should be considered separately because diagnosis and treatment are often unique in the nursing home setting. Patients with human immunodeficiency virus (HIV) and other forms of immunodeficiency were not included because these patients require consideration of a large number of opportunistic infections.

Hospital-acquired pneumonia: Nosocomial pneumonia is the second most common hospital-acquired infection and the one that is most commonly fatal. The
TABLE 6

Suggested diagnostic tests for community-acquired pneumonia

\begin{tabular}{ll}
\hline Test & Rationale \\
\hline Chest x-ray & $\begin{array}{l}\text { Confirm suspected pneumonia } \\
\text { Rule out effusion or abscess } \\
\text { Determine extent of } \\
\text { involvement }\end{array}$ \\
$\begin{array}{l}\text { Blood work including blood } \\
\text { cultures, oximetry or } \\
\text { arterial blood gases } \\
\text { Thoracentesis }\end{array}$ & $\begin{array}{l}\text { to be admitted } \\
\text { Rule out empyema if effusion is } \\
\text { greater than } 10 \text { mm on lateral } \\
\text { decubitus view or patient is } \\
\text { toxic }\end{array}$ \\
\hline
\end{tabular}

overall mortality rate in Canada is estimated to be $32 \%$ (10). The incidence varies greatly depending on the type of medical service - Canadian tertiary care hospitals report incidence rates between 2.5 per 1000 admissions to the gynecology service and 67 per 1000 in the intensive care unit (8). Family physicians are rarely called upon to treat hospital-acquired pneumonia, and this condition was not addressed by the panel.

\section{THE USE OF ANTIBIOTICS IN URINARY TRACT INFECTIONS AND PROSTATITIS}

Thirty-five per cent of women aged 20 to 40 years will have at least one urinary tract infection (UTI) in their lifetime. In the general population, there are 25 times more UTIs in females than in males, although in institutional settings, the ratio is equivalent.

Over the past decade, the management of acute and recurrent cystitis and uncomplicated pyelonephritis has advanced, and there is now a general consensus on treatment (12). Conversely, there have been few advances in the management of complicated UTIs or chronic prostatitis, and antibiotic regimens for these conditions remain empirical (13).

Acute uncomplicated UTI: Because the infecting organisms and their antimicrobial susceptibility profiles are predictable in young, healthy, nonpregnant females with typical symptoms of acute uncomplicated cystitis, pretreatment urine cultures are not recommended in this population. The diagnosis can be presumed if pyuria is present on microscopy or leukocyte esterase testing. A short course of empirical antimicrobial therapy can be prescribed. No follow-up visit or culture after therapy is necessary unless symptoms persist or recur. If pyuria is 
TABLE 7

Antibiotic treatment of community-acquired pneumonia

\section{Grade D recommendations}

Patient characteristics

Organisms

\section{Group 1}

Healthy out-patients

Less than 65 years of age

No comorbidity

\section{Group 2 non-nursing home patients}

More than 65 years of age

With comorbidity

Do not require hospitalization
S pneumoniae

Respiratory viruses

$H$ influenzae

Aerobic Gram-negative

bacilli

$S$ aureus

C pneumoniae

Legionella species

$M$ tuberculosis

Endemic fungi

\section{Group 2 nursing home patients}

Oral therapy required

Evidence of respiratory distress

Evidence of consolidation
Streptococcus pneumoniae

Mycoplasma pneumoniae

Respiratory viruses

Chlamydia pneumoniae

Haemophilus influenzae

Legionella species

Staphylococcus aureus

Mycobacterium tuberculosis

Endemic fungi (depending

on geographic location)

\section{$S$ pneumoniae \\ $H$ Influenzae \\ Anaerobes \\ Gram-negative bacilli \\ $S$ aureus \\ C pneumoniae \\ Legionella species}

\section{Antibiotic recommendations}

Erythromycin $1 \mathrm{~g} /$ day in divided doses for 10 days

If macrolide allergy, use doxycycline $200 \mathrm{mg}$ first day, then

$100 \mathrm{mg}$ once daily for nine days

If gastrointestinal intolerance or a smoker, azithromycin $500 \mathrm{mg}$ first day, then $250 \mathrm{mg}$ for four days or clarithromycin 250 to $500 \mathrm{mg}$ bid for 10 days

Amoxicillin/clavulanate 500/125 mg tid for 10 days or cefaclor $500 \mathrm{mg}$ tid for 10 days or cefuroxime axetil $500 \mathrm{mg}$ bid for 10 days

If allergic to penicillin, use co-trimoxazole $160 / 800 \mathrm{mg}$ bid for 10 days

If C pneumoniae or Legionella species are a concern add erythromycin $2 \mathrm{~g} /$ day in divided doses for 10 days or clarithromycin $500 \mathrm{mg}$ bid for 10 days or azithromycin $500 \mathrm{mg}$ on day 1 , then $250 \mathrm{mg}$ daily for four days

Amoxicillin/clavulanate 500/125 mg tid or cefuroxime axetil $500 \mathrm{mg}$ bid or cefaclor $500 \mathrm{mg}$ tid or co-trimoxazole $160 / 800 \mathrm{mg}$ bid

If C pneumoniae or Legionella species are a concern, add erythromycin $1 \mathrm{~g} /$ day in divided doses

In the severely ill, use amoxicillin $500 \mathrm{mg}$ tid with ciprofloxacin 500 to $750 \mathrm{mg}$ bid for 10 days or cefuroxime axetil $500 \mathrm{mg}$ bid for 10 days with erythromycin $1 \mathrm{~g}$ /day in divided doses

If allergic to penicillin, use clindamycin 300 to $450 \mathrm{mg}$ tid with ciprofloxacin 500 to $750 \mathrm{mg}$ bid for 10 days

If $C$ pneumoniae or Legionella species are a concern, add erythromycin $2 \mathrm{~g} /$ day in divided doses

S pneumoniae

$H$ influenzae

Polymicrobial (including anaerobes) aerobic Gram-negative bacilli

Saureus

$M$ pneumoniae

C pneumoniae

Respiratory viruses

Legionella species
Cefuroxime $750 \mathrm{mg}$ intravenously every $8 \mathrm{~h}$ or ceftriaxone $1 \mathrm{~g}$ intravenous or intramuscular every $24 \mathrm{~h}$ or cefotaxime $1 \mathrm{~g}$ intravenous every $8 \mathrm{~h}$

If allergic to cephalosporin, use co-trimoxazole 160 to $240 / 800$ to $1200 \mathrm{mg}$ intravenous every 6 to $8 \mathrm{~h}$ with or without erythromycin

If C pneumoniae or Legionella species are a concern, add erythromycin 2 to $4 \mathrm{~g} /$ day in divided doses for 14 days 
TABLE 7 continued

Antibiotic treatment of community-acquired pneumonia

\section{Grade D recommendations}

Patient characteristics

\section{Group 4}

Severely ill patients

Require intensive care unit therapy

High risk of mortality

\section{Organisms}

$S$ pneumoniae

Legionella species

Aerobic Gram-negative bacilli

$M$ pneumoniae

Respiratory viruses

$H$ influenzae

C pneumoniae

Antibiotic recommendations

Intravenous or intramuscular ceftriaxone 1 g every $24 \mathrm{~h}$ or cefotaxime $1 \mathrm{~g}$ intravenous every $8 \mathrm{~h} *$

If Pseudomonas aeruginosa or antibiotic-resistant

Gram-negatives are a concern, use intravenous piperacillin/tazobactam 3/0.375 g every $6 \mathrm{~h}$ or intravenous imipenem/cilastatin 500/100 g every $6 \mathrm{~h}$ of each or intravenous meropenem $1 \mathrm{~g}$ every $8 \mathrm{~h}$ or intravenous ciprofloxacin 400 mg every $12 \mathrm{~h}$

Add erythromycin 2 to $4 \mathrm{~g} /$ day in divided doses to cover Legionella species, M pneumoniae or C pneumoniae

When Pseudomonas species are suspected, combination therapy is required, eg, ceftazidime, piperacillin, piperacillin/tazobactam, imipenem/cilastatin, meropenem or ciprofloxacin in combination with an aminoglycoside

*With the exception of ceftriaxone, the antibiotics may have to be adjusted for impaired renal function. Comorbidity: Chronic obstructive lung disease, diabetes mellitus, renal insufficiency, congestive heart failure, hospitalization within previous year, postsplenectomy state, chronic alcoholism, malnutrition, altered mental status or suspected aspiration

TABLE 8

Antibiotic recommendations for acute cystitis in women

\begin{tabular}{lll}
$\begin{array}{l}\text { Grade A recommendations } \\
\text { Considerations }\end{array}$ & Antibiotic & Dose \\
\hline Uncomplicated presentation & Co-trimoxazole & $160 / 800 \mathrm{mg}$ bid for three days \\
Postmenopausal & Co-trimoxazole & $160 / 800 \mathrm{mg}$ bid for seven days \\
Allergy to sulfa & Trimethoprim & $100 \mathrm{mg}$ bid for three days \\
& or nitrofurantoin & 50 to $100 \mathrm{mg}$ qid for three days \\
Intolerant to first-line antibiotic & Amoxicillin/clavulanate or & $250 / 125 \mathrm{mg}$ tid for three days \\
& ciprofloxacin or & $100 \mathrm{to} 250 \mathrm{mg}$ bid for three days \\
& ofloxacin or & $200 \mathrm{mg}$ bid for three days \\
\hline
\end{tabular}

It should be noted that resistance rates to co-trimoxazole continue to rise and currently are in the order of $15 \%$ to $20 \%$ in the Canadian prairie provinces

absent, or there are atypical clinical features or factors that suggest a complicated infection, a culture should be performed before therapy is started. In males, a culture is generally recommended.

The efficacy of a three-day course of antibiotic is well documented (Table 8) (14-18). However, patients should be advised that some symptoms will not resolve immediately and may continue for more than three days.

Acute cystitis is very uncommon in young men. Sexual activity is a risk factor, whether the patient is heterosexual (19) or homosexual (20). Because of the relative rarity of the condition there are no controlled 
TABLE 9

Antibiotic treatment of recurrent cystitis

\begin{tabular}{|c|c|c|}
\hline Type of Recurrence & Antibiotic options & Dose and duration \\
\hline \multicolumn{3}{|l|}{ Grade $\mathrm{A}$ recommendations } \\
\hline \multirow[t]{4}{*}{$\begin{array}{l}\text { Frequent reinfections (three or } \\
\text { more infections per year) }\end{array}$} & $\begin{array}{l}\text { Continuous prophylaxis } \\
\text { at bedtime }\end{array}$ & $\begin{array}{l}\text { Co-trimoxazole } 40 / 200 \mathrm{mg} \text { once daily at bed time or every } \\
\text { other night for six months }\end{array}$ \\
\hline & & $\begin{array}{l}\text { If allergy to sulfa, nitrofurantoin } 50 \text { to } 100 \mathrm{mg} \text { once daily at } \\
\text { bedtime or } \\
\text { trimethoprim } 100 \mathrm{mg} \text { once daily at bedtime } \\
\text { If intolerant or resistant, norfloxacin } 200 \mathrm{mg} \text { once daily at } \\
\text { bedtime }\end{array}$ \\
\hline & Postcoital prophylaxis & $\begin{array}{l}\text { Co-trimoxazole } 40 \text { to } 80 / 200 \text { to } 400 \mathrm{mg} \text { single dose } \\
\text { If allergy to sulfa, nitrofurantoin } 50 \text { to } 100 \mathrm{mg} \text { single dose or } \\
\text { cephalexin } 250 \mathrm{mg} \text { single dose or } \\
\text { ciprofloxacin } 250 \mathrm{mg} \text { single dose }\end{array}$ \\
\hline & Intermittent self-therapy & $\begin{array}{l}\text { Co-trimoxazole } 320 / 1600 \mathrm{mg} \text { as a single dose or } \\
\text { co-trimoxazole } 160 / 800 \mathrm{mg} \text { bid for three days or } \\
\text { any of the aforementioned antibiotics for three days (grade } \\
\text { D recommendations) }\end{array}$ \\
\hline \multicolumn{3}{|l|}{ Grade $\mathrm{D}$ recommendations } \\
\hline \multirow{2}{*}{$\begin{array}{l}\text { Early Recurrence/relapse } \\
\text { (recurrence within four weeks } \\
\text { of first infection) } \\
\text { Urine culture required }\end{array}$} & $\begin{array}{l}\text { Second course of first-line } \\
\text { antibiotic or }\end{array}$ & $\begin{array}{l}\text { Co-trimoxazole } 160 / 800 \mathrm{mg} \text { bid for seven days or } \\
\text { trimethoprim } 100 \mathrm{mg} \text { bid for seven days or } \\
\text { nitrofurantoin } 50 \text { to } 100 \mathrm{mg} \text { qid for seven days }\end{array}$ \\
\hline & second-line antibiotic & $\begin{array}{l}\text { Amoxicillin/clavulanate } 250 \text { to } 500 / 125 \mathrm{mg} \text { tid for seven } \\
\text { days or ciprofloxacin } 250 \mathrm{mg} \text { bid for seven days or } \\
\text { ofloxacin } 200 \mathrm{mg} \text { bid for seven days or } \\
\text { norfloxacin } 400 \mathrm{mg} \text { bid for seven days }\end{array}$ \\
\hline
\end{tabular}

treatment studies. A seven-day course of co-trimoxazole will cure most patients, and prolonged antibiotic therapy (four to six weeks of co-trimoxazole or a quinolone) is reserved for patients who develop recurrence (21).

Recurrent cystitis: Patients whose cystitis recurs after a three-day course of treatment for acute cystitis were stratified by the panel into two groups: those who relapse (early recurrence with the same organism within four weeks) and those who have reinfections. Patients who relapse should have culture and susceptibility testing performed and require a second seven-day course of treatment (Table 9). For patients with frequent reinfections (more than three in the preceding year), there are several options available - continuous low-dose prophylaxis (21-24), postcoital prophylaxis (25-27) and intermittent self-therapy (28). Patient involvement is important in selecting the most appropriate strategy.

Acute uncomplicated pyelonephritis: Symptoms of acute pyelonephritis are fever, flank pain and, in some cases, lower urinary tract symptoms. A midstream urine culture is recommended. In patients who are severely ill, are hemodynamically unstable, or have signs of septicemia or septic shock, hospital admission and parenteral therapy (Table 10) are indicated (29). If the patient fails to improve in 48 to $72 \mathrm{~h}$, the likelihood of a complicated infection or a resistant pathogen must be considered. Investigation with a renal sonogram or computerized tomography should be considered in patients who are hemodynamically unstable or fail to improve. All patients should have a follow-up urine culture five to nine days after completion of therapy because there is a relapse rate of approximately $30 \%$. Stable patients without nausea and vomiting can be managed safely with oral antibiotics on an out-patient basis (30).

Acute pyelonephritis in pregnancy usually requires admission to hospital, and treatment with parenteral ampicillin and gentamicin (12). Quinolones are contraindicated in pregnancy. 
Table 10

Antibiotic treatment of uncomplicated pyelonephritis:

\begin{tabular}{|c|c|c|}
\hline Patient characteristics & Antibiotic & Dosage and duration \\
\hline \multirow{5}{*}{$\begin{array}{l}\text { Mild acute pyelonephritis: } \\
\text { No nausea or vomiting } \\
\text { Can tolerate oral therapy }\end{array}$} & Co-trimoxazole or & $160 / 800 \mathrm{mg}$ bid for 14 days \\
\hline & ciprofloxacin or & $500 \mathrm{mg}$ bid for 14 days \\
\hline & norfloxacin or & $400 \mathrm{mg}$ bid for 14 days \\
\hline & ofloxacin or & $200 \mathrm{mg}$ bid for 14 days \\
\hline & amoxicillin/clavulanate & $250 / 125$ to $500 / 125 \mathrm{mg}$ tid for 14 days \\
\hline \multirow{2}{*}{$\begin{array}{l}\text { Severe systemic illness: } \\
\text { Nausea and vomiting } \\
\text { Possible urosepsis } \\
\text { Overnight admission to hospital or } \\
\text { observation unit necessary }\end{array}$} & Gentamicin intravenous & $\begin{array}{l}1.5 \mathrm{mg} / \mathrm{kg} / \text { day intravenous } 8 \mathrm{~h} \text { or once daily ( } 5 \text { to } \\
7 \mathrm{mg} / \mathrm{kg} / \text { day) }\end{array}$ \\
\hline & $\begin{array}{l}\text { with or without ampicillin } \\
\text { intravenous }\end{array}$ & 1 to $2 \mathrm{~g}$ intravenous every 4 to $6 \mathrm{~h}$ \\
\hline \multirow{4}{*}{$\begin{array}{l}\text { When clinically improved, switch to } \\
\text { oral therapy based on urine culture } \\
\text { results }\end{array}$} & Co-trimoxazole or & $160 / 800 \mathrm{mg}$ bid for 14 days \\
\hline & ciprofloxacin or & $500 \mathrm{mg}$ bid for 14 days \\
\hline & norfloxacin or & $400 \mathrm{mg}$ bid for 14 days \\
\hline & ofloxacin & $200 \mathrm{mg}$ bid for 14 days \\
\hline
\end{tabular}

TABLE 11

Antibiotics to be used in acute pyelonephritis in pregnancy

\section{Antibiotic}
First-line
Intravenous gentamicin $1.5 \mathrm{mg} / \mathrm{kg}$ every $8 \mathrm{~h}$ or once daily ( 5 to $7 \mathrm{mg} / \mathrm{kg} /$ day) with intravenous ampicillin 1 to 2 g every 4 to $6 \mathrm{~h}$

\section{Second-line}

Intravenous cefotaxime $1 \mathrm{~g}$ every $8 \mathrm{~h}$

Ceftriaxone $1 \mathrm{~g}$ every $24 \mathrm{~h}$

This regimen is to be followed by one with an oral antibiotic appropriate for use during pregnancy to complete a two-week course

The recommendations defined below were derived from a substantial amount of clinical work in this area (31-33). Local resistance patterns must also be considered when choosing antibiotic therapy.

Asymptomatic bacteriuria: Bacteriuria is common in the elderly, and the majority of patients are asymptomatic (34). Treatment is associated with a high inci- dence of recurrence and may lead to development of antibiotic-resistant organisms (35). Untreated patients do not appear to have a higher morbidity or mortality rate. For this reason, asymptomatic infections are not routinely treated, although infections should be eradicated before genitourinary surgery or insertion of a prosthesis. In younger patients, the significance and management of asymptomatic bacteriuria is less clear. It should be eradicated in pregnant females, but repeated treatment of asymptomatic bacteriuria in healthy young females is not warranted (36).

\section{Asymptomatic bacteriuria}

No treatment except before instrumentation of the urinary tract or prosthetic surgery and during pregnancy.

UTI in pregnancy: Patients with UTIs during pregnancy should be treated whether symptomatic or not (Table 11) (37). Approximately $30 \%$ of females with untreated asymptomatic bacteriuria in pregnancy develop acute 
symptomatic infection later in pregnancy, which may be associated with premature delivery (38). The choice of antibiotics in pregnancy is limited, and quinolones are contraindicated (Table 12) $(12,39,40)$. Management of acute pyelonephritis in pregnancy usually requires admission to hospital and treatment with parenteral therapy, although out-patient therapy is safe and effective in selected patients.

Catheter-associated UTI: Treatment of asymptomatic bacteriuria in patients with indwelling catheters has minimal benefit (41). Infection should be treated before urological surgery or insertion of a prosthesis (42). Within two weeks of catheter removal, $25 \%$ of untreated patients become symptomatic with either upper or lower UTI (43).

Although diagnosis of infection is often difficult, approximately $50 \%$ of febrile episodes in patients with in-
TABLE 12

Antibiotics that may be used in pregnancy

\begin{tabular}{|c|c|}
\hline Antibiotic & Concerns \\
\hline $\begin{array}{l}\text { Cephalexin } 250 \text { mg qid for } \\
\text { three to seven days }\end{array}$ & \\
\hline $\begin{array}{l}\text { Nitrofurantoin } \\
50 \text { to } 100 \mathrm{mg} \text { qid for three } \\
\text { to seven days }\end{array}$ & $\begin{array}{l}\text { Risk of hemolytic anemia in } \\
\text { G6PD deficient patients }\end{array}$ \\
\hline $\begin{array}{r}\text { Co-trimoxazole } 160 / 800 \mathrm{mg} \\
\text { bid for three to seven days }\end{array}$ & $\begin{array}{l}\text { Risk of kernicterus if used near } \\
\text { term } \\
\text { Possible teratogenesis }\end{array}$ \\
\hline $\begin{array}{l}\text { Amoxicillin } 250 \text { to } 500 \mathrm{mg} \\
\text { tid for three to seven days }\end{array}$ & High resistance rates \\
\hline
\end{tabular}

It is recommended that a follow-up urine sample be taken

TABLE 13

Antibiotic treatment of prostatitis

\begin{tabular}{|c|c|c|}
\hline Type of Prostatitis & Antibiotic & Dose \\
\hline \multicolumn{3}{|c|}{ Grade $B$ recommendations } \\
\hline \multirow[t]{6}{*}{ Acute bacterial } & Ampicillin with & 1 to $2 \mathrm{~g}$ intravenous every 4 to $6 \mathrm{~h}$ \\
\hline & gentamicin followed by & $\begin{array}{l}3 \text { to } 5 \mathrm{mg} / \mathrm{kg} / \text { day intravenous every } 8 \mathrm{~h} \text { or } \\
5 \text { to } 7 \mathrm{mg} / \mathrm{kg} / \text { day once daily }\end{array}$ \\
\hline & co-trimoxazole or & $160 / 800 \mathrm{mg}$ bid orally for four to six weeks \\
\hline & ciprofloxacin or & $500 \mathrm{mg}$ bid orally for four to six weeks \\
\hline & norfloxacin or & $400 \mathrm{mg}$ bid orally for four to six weeks \\
\hline & ofloxacin & $300 \mathrm{mg}$ bid orally for four to six weeks \\
\hline
\end{tabular}

\section{Grade A recommendations}

Chronic bacterial

$$
\begin{aligned}
& \text { Co-trimoxazole or } \\
& \text { ciprofloxacin or } \\
& \text { norfloxacin or } \\
& \text { ofloxacin }
\end{aligned}
$$

\section{Grade D recommendations}

Chronic nonbacterial

\author{
Co-trimoxazole or \\ erythromycin or \\ ciprofloxacin or \\ ofloxacin or \\ doxycycline
}

$160 / 800 \mathrm{mg}$ bid orally for six to 12 weeks

$500 \mathrm{mg}$ bid orally for six to 12 weeks

$400 \mathrm{mg}$ bid orally for six to 12 weeks

$300 \mathrm{mg}$ bid orally for six to 12 weeks

$160 / 800 \mathrm{mg}$ bid orally for four to six weeks

$500 \mathrm{mg}$ bid orally for four to six weeks

250 to $500 \mathrm{mg}$ bid orally for four to six weeks

$300 \mathrm{mg}$ bid orally for four to six weeks

$100 \mathrm{mg}$ bid orally for four to six weeks 
TABLE 14

Investigation of diabetic foot infections

\begin{tabular}{ll} 
Objectives & Considerations \\
\hline Assess neuropathy & - Testing for pain, temperature and vibration sensation reinforces \\
& patient's education regarding the role of recurring trauma \\
- The nylon monofilament test of pain/touch is a quick effective & monitoring device $(57,58)$
\end{tabular}

Assess perfusion

Cultures as a guide to antimicrobial treatment

Imaging studies
- In addition to large vessel arterial occlusive disease, peripheral vascular bypass grafts in the lower leg have reduced amputation rates $(59,60)$

- Adequate perfusion is often a prerequisite for optimal outcome

- Aerobic culture results can be used to guide antibiotic selection, keeping in mind situations where anaerobic coverage is required. Culture-guided therapy is the most cost effective strategy (61)

- X-rays: Baseline and serially as clinically indicated

- Bone and white blood cell scans are not cost effective in uncomplicated infections (61) dwelling catheters appear to originate from the urinary tract (44). Parenteral treatment with ampicillin and gentamicin for 48 to $72 \mathrm{~h}$ until afebrile was recommended (12).

Grade B recommendations for catheter-associated urinary tract infection (catheter in situ)

- Asymptomatic bacteriuria - No treatment except before urological or prosthetic surgery

- Symptomatic infection - Parenteral ampicillin and gentamicin until afebrile for 48 to $72 \mathrm{~h}$

Prostatitis: Acute prostatitis (Table 13) is a severe systemic illness characterized by a tender enlarged prostate, dysuria and urinary retention. Admission to hospital is often required.

Stratification of chronic prostatitis has proven to be of limited value in developing guidelines for patient treatment. Diagnosis remains difficult because localization studies are time consuming, expensive and can cause discomfort to the patient. Treatment with antibiotics is moderately successful, and short term cure rates of $60 \%$ have been reported (45-47). The relapse rate following antibiotic treatment for chronic bacterial prostatitis is high.

The cause of chronic nonbacterial prostatitis is largely unknown. In the absence of inflammatory cells in prostatic secretions or bacteriuria, prolonged antibiotic therapy is not indicated.

Complicated UTIs: UTIs are associated with an underlying urinary tract abnormality, which may be caused by stones, recent urological surgery or renal cystic disease, or may be due to a significant systemic disorder such as diabetes, immunosuppression or a neurogenic bladder. There have been few controlled clinical trials, and therapy must be individualized according to presenting symptoms and comorbidity (12). The majority of patients are managed in the same way as those with acute pyelonephritis. Radiological investigation and urological consultation are often necessary.

\section{ANTIBIOTIC TREATMENT OF DIABETIC FOOT INFECTIONS}

Assessment and investigation: Diabetes mellitus affects close to $5 \%$ of the Canadian population, and foot infections are the most common reason for hospital admission among diabetics. At least half of the foot amputations performed each year are the result of diabetic foot infections (48).

The pathogenetic processes leading to foot infection include peripheral neuropathy and occlusive vascular disease involving arteries in the lower third of the leg (49), each of which are accelerated by poor diabetic control (50). Recurrent (and unappreciated) trauma and re- 
TABLE 15

Antibiotic treatment for diabetic foot infections

Grade D recommendations

\begin{tabular}{|c|c|c|c|}
\hline Infection & Patient characteristics & Organism coverage & Antibiotic, dose and duration \\
\hline $\begin{array}{l}\text { Superficial } \\
\text { uncomplicated }\end{array}$ & $\begin{array}{l}\text { - } 80 \% \text { of initial presentations } \\
\text { - one month duration } \\
\text { - } 2 \mathrm{~cm} \text { inflammation } \\
\text { - Negative probe to bone } \\
\text { - Negative x-ray for } \\
\text { osteomyelitis }\end{array}$ & $\begin{array}{l}\text { Staphylococcus aureus } \\
\text { Streptococcus species } \\
\text { Anaerobes }\end{array}$ & $\begin{array}{l}\text { Cephalexin } 500 \text { to } 1000 \mathrm{mg} \text { qid for } 14 \text { days or } \\
\text { co-trimoxazole } 320 / 1600 \mathrm{mg} \text { bid for } 14 \text { days or } \\
\text { amoxicillin clavulanate } 500 / 125 \mathrm{mg} \text { tid for } 14 \\
\text { days or } \\
\text { cloxacillin } 500 \text { to } 1000 \mathrm{mg} \text { qid for } 14 \text { days* } \\
\text { If penicillin allergy, clindamycin } 300 \mathrm{mg} \text { tid for } \\
14 \text { days }\end{array}$ \\
\hline $\begin{array}{l}\text { Complicated } \\
\text { nonlimb } \\
\text { threatening }\end{array}$ & $\begin{array}{l}\text { - } 20 \% \text { of infections } \\
\text { - Acute aggressive } \\
\text { - Chronic progressive } \\
\text { - } 2 \mathrm{~cm} \text { cellulitis } \\
\text { - } \text { Deep soft tissue involvement } \\
\text { - Bone or joint involvement } \\
\text { - Out-patient management }\end{array}$ & $\begin{array}{l}\text { Saureus } \\
\text { Streptococcus species } \\
\text { Anaerobes } \\
\text { Coliforms (enteric } \\
\text { Gram-negative bacilli) }\end{array}$ & $\begin{array}{l}\text { Cephalexin } 500 \text { to } 1000 \mathrm{mg} \text { qid for } 2 \text { to } 12 \\
\text { weeks with metronidazole } 500 \mathrm{mg} \text { bid for two } \\
\text { to } 12 \text { weeks or } \\
\text { co-trimoxazole } 320 / 1600 \mathrm{mg} \text { bid for two to } 12 \\
\text { weeks }^{+} \text {with metronidazole } 500 \mathrm{mg} \text { bid for two } \\
\text { to } 12 \text { weeks or } \\
\text { amoxicillin/clavulanate } 500 / 125 \mathrm{mg} \text { tid for two } \\
\text { to } 12 \text { weeks or } \\
\text { co-trimoxazole } 320 / 1600 \mathrm{mg} \text { bid for two to } 12 \\
\text { weeks with clindamycin } 300 \mathrm{mg} \text { qid for two to } \\
12 \text { weeks or } \\
\text { clindamycin } 300 \mathrm{mg} \text { qid for two to } 12 \text { weeks } \\
\text { with ciprofloxacin } 500 \mathrm{mg} \text { bid for two to } 12 \\
\text { weeks }\end{array}$ \\
\hline \multirow[t]{2}{*}{$\begin{array}{l}\text { Limb and } \\
\text { life-threatening } \\
\text { infections }\end{array}$} & $\begin{array}{l}\text { - Acutely evolving } \\
\text { - Sepsis } \\
\text { - Bacteremia } \\
\text { - In-patient management } \\
\text { including surgical } \\
\text { intervention if necessary }\end{array}$ & $\begin{array}{l}\text { S aureus } \\
\text { Streptococcus species } \\
\text { Anaerobes } \\
\text { Coliforms (enteric } \\
\text { Gram-negative bacilli) } \\
\text { Add aminoglycoside for } 48 \\
\text { to } 72 \mathrm{~h} \text { pending cultures } \\
\text { if hospital-acquired } \\
\text { Gram-negative bacilli is } \\
\text { suspected }\end{array}$ & $\begin{array}{l}\text { Intravenous ceftriaxone } 1 \text { g every } 24 \text { h with } \\
\text { intravenous metronidazole } 500 \text { mg every } 8 \text { h or } \\
\text { intravenous clindamycin } 600 \text { mg every } 8 \text { h or } \\
\text { intravenous cefotaxime } 1 \text { g every } 8 \text { h with } \\
\text { intravenous metronidazole } 500 \text { mg every } 8 \text { h or } \\
\text { intravenous clindamycin } 600 \text { mg every } 8 \mathrm{~h}\end{array}$ \\
\hline & & $\begin{array}{l}\text { Broad spectrum coverage } \\
\text { including } \\
\text { antipseudomonal } \\
\text { coverage } \\
\text { Add aminoglycoside for } 48 \\
\text { to } 72 \mathrm{~h} \text { pending cultures }\end{array}$ & $\begin{array}{l}\text { Intravenous piperacillin/tazobactam } 4.5 \text { g every } \\
8 \mathrm{~h} \text { or } \\
3.375 \mathrm{~g} \text { every } 6 \mathrm{~h} \text { or } \\
\text { intravenous ceftazidime } 1 \text { to } 2 \mathrm{~g} \text { with } \\
\text { intravenous clindamycin } 600 \mathrm{mg} \text { every } 8 \mathrm{~h} \text { or } \\
\text { intravenous imipenem/cilastatin } 500 / 500 \mathrm{mg} \\
\text { every } 6 \mathrm{~h}\end{array}$ \\
\hline
\end{tabular}

*Add metronidazole 250 to $500 \mathrm{mg}$ bid for 14 days if patient responds suboptimally; ${ }^{\dagger}$ For osteomyelitis

duced tissue perfusion increase the susceptibility of the foot to soft tissue infection, or to ulceration and chronic microbial colonization of foot lesions (51). Subsequent deeper infection of joints, bone or soft tissue planes may supervene.
When examining the infected foot (Table 14), the extent of cellulitis, necrosis and abscess formation and the presence of osteomyelitis must be assessed. A pedal pulse evaluation is important, and if the vascular system is compromised, further investigation with Doppler 
ultrasound and angiography may be necessary. The chronic stable neuropathic foot ulcer, though colonized by microbes, seldom requires antimicrobial therapy. In this situation, treatment should be directed at relief from pressure and foot trauma (52).

Carefully obtained cultures are useful to guide antimicrobial selection. Superficial swabs are discouraged because surface contaminants are mixed with potential pathogens. More reliable cultures are collected from curettage material from a cleaned ulcer base, excised deep tissue or sinus cultures, particularly when probing of the sinus leads to subjacent bone (53). A wire swab, used elsewhere for urethral cultures, is a convenient tool to probe draining sinuses. When the wire probe leads to bone, there is an $89 \%$ positive predictive value for underlying osteomyelitis, a finding that reduces the need for nuclear imaging studies (53). In cases of osteomyelitis, especially when necrotic bone is present, open debridement of infected tissue provides more reliable culture material.

Aerobic and anaerobic cultures usually reveal a polymicrobial infection, particularly in chronic and deep infections (51,54). Predominant pathogens include Staphylococcus aureus, anaerobic Gram-positive cocci, Bacteroides species, and enteric Gram-negative bacilli. On the other hand, early acute infections are more likely to involve streptococcal and staphylococcal organisms as primary pathogens - Gram-negative organisms recovered from ulcer lesions are more likely colonizers in this situation (55).

Treatment: A team approach involving diabetology, diagnostic imaging, peripheral vascular surgery, orthopedic surgery, foot clinics and home care was

\section{REFERENCES}

1. Evans KL. Diagnosis and management of sinusitis, BMJ 1994;309:1415-22.

2. Van Buchem FL, Knottnerus JA, Schrijnemaekers VJ, Peeters MF. Primary-care-based randomised placebo-controlled trial of antibiotic treatment in acute maxillary sinusitis. Lancet 1997;349:683-7.

3. Axelsson A, Chidekel N, Grebelius N, et al. Treatment of acute maxillary sinusitis: a comparison of four different methods. Acta Otolaryngol 1970;70:71-6.

4. Low DE, Desrosiers M, McSherry J, et al. A practical guide for the diagnosis and treatment of acute sinusitis. Can Med Assoc J 1997;156(Suppl 6):S1-S14.

5. Scriver SR, Walmsley SL, Kau CL, et al. Determination of antimicrobial susceptibilities of Canadian isolates of Haemophilus influenzae and characterization of their beta-lactamases. Antimicrob Agents Chemother 1994;38:1678-80.

6. Balter MS, Hyland RH, Low DE, et al. Chairs, speakers and participants in the Canadian Bronchitis Symposium. Recommendations on the management of chronic bronchitis. Can Med Assoc J 1994;151(Suppl 10):1-23. recommended for the treatment of foot infections (56$60)$. Interventions include relief of trauma, pressure release, debridement of necrotic tissue, good diabetic control and referral to foot care. When indicated, vascular reconstructive surgery, including pedal bypass, was shown to reduce amputations and accelerate healing. Antibiotic therapy (Table 15) can be initiated empirically on clinical grounds, but subsequent therapy should depend on the type of pathogens recovered from cultures.

The duration of therapy of acute cellulitis is generally 10 to 14 days. If patients are started on intravenous therapy, stepdown to oral therapy should be considered once the infection is controlled (61). For patients with underlying osteomyelitis, prolonged therapy for as long as 12 to 15 weeks is required for durable cures $(62,63)$. Surgical debridement of dead bone is essential for cure.

Regarding the recommendations for antimicrobial therapy, equivalent outcomes are expected for each of the choices within each patient grouping. Ranking or selection is based on convenience, cost and adverse effect profiles. Enterococcal coverage may need to be considered when this organism is shown to persist in serial cultures from patients responding suboptimally, or when the organism is recovered in limb and lifethreatening infections.

ACKNOWLEDGEMENTS: Both the meeting and this publication were made possible through an unrestricted educational grant from Bayer Inc, Healthcare Division. The conference panel had full control over the content of the guidelines.

We would also like to thank Barnes, Daly, Fenwick and Associates for their assistance in the organization of the workshop and Wendy Wilson for her contributions to the preparation of this manuscript.

7. Anthonisen NR, Manfreda J, Warren CPW, et al. Antibiotic therapy in exacerbations of chronic obstructive pulmonary disease. Ann Intern Med 1987;106:196-204.

8. Mandell LA, Niederman M, the Canadian Community Acquired Pneumonia Consensus Conference Group. Antimicrobial treatment of community acquired pneumonia in adults: a conference report. Can J Infect Dis 1993:4:25-8.

9. Marrie TJ, Durant H, Yates L. Community-acquired pneumonia requiring hospitalization: 5-year prospective study. Rev Infect Dis 1989;11:586-99.

10. MacFarlane JT, Miller AC, Roderick WH, Morris AH, Rose $\mathrm{DH}$. Comparative radiographic features of community acquired legionnaire's disease, pneumococcal pneumonia, mycoplasma pneumonia and psittacosis. Thorax 1984;39:28-33.

11. Mandell LA, Marrie TM, Niederman MS, the Canadian Hospital Acquired Pneumonia Conference Group. Initial antimicrobial treatment of hospital acquired pneumonia in adults: A conference report. Can J Infect Dis 1993;4:317-21. 
12. Ronald AR, Nicolle LE, Harding GKM. Standards of therapy for urinary tract infections in adults. Infection 1992;20:S164-70.

13. Ronald AR, Harding GKM. Complicated urinary tract infections. Infect Dis Clin N Am 1997;11:583-92.

14. Norrby SR. Short-term treatment of uncomplicated lower urinary tract infections in women. Rev Infect Dis 1990;12:458-67.

15. Hooton TM, Johnson C, Winter C, et al. Single-dose and three-day regimens of ofloxacin versus trimethoprim-sulfamethoxazole for acute cystitis in women. Antimicrob Agents Chemother 1991;35:1479-83.

16. Saginur R, Nicolle LE, The Canadian Infectious Disease Society Clinical Trials Study Group. Single-dose compared with three days norfloxacin for treatment of uncomplicated urinary infection in women. Arch Intern Med 1992;152:1233-7.

17. Norrby SR. Treatment of urinary tract infections with quinolone antimicrobial agents. In: Hooper DC, Wolfson JS, eds. Quinolone Antimicrobial Agents, 2nd edn. Washington: American Society for Microbiology, 1993.

18. Nicolle LE, DuBois J, Martel AY, Harding GK, Shafran SD, Conly JM. Treatment of uncomplicated urinary tract infections with 3 days lomefloxacin compared with treatment with 3 days of norfloxacin. Antimicrob Agents Chemother 1993;37:574-9.

19. Krieger JN, Ross SO, Simonsen JM. Urinary tract infections in health university men.

J Urol 1993;149:1046-8.

20. Barnes RC, Daifuku R, Roddy RE, Stamm WE. Urinary-tract infection in sexually active homosexual men. Lancet 1986;i:171.

21. Nicolle LE, Ronald AR. Recurrent urinary tract infection in adult women: diagnosis and treatment. Infect Dis Clin North Am 1987;1:793.

22. Nicolle LE, Harding GKM, Thompson M, Kennedy J, Urias B, Ronald AR. Efficacy of five years of continuous, low-dose trimethoprim-sulfamethoxazole prophylaxis for urinary tract infections. J Infect Dis $1988 ; 157: 1239-42$.

23. Harding GKM, Ronald AR. A controlled study of antimicrobial prophylaxis of recurrent infection in women. N Eng J Med 1974;291:597-601.

24. Brumfitt W, Hamilton-Miller JM. Prophylactic antibiotics for recurrent urinary tract infections. J Antimicrob Chem 1990;25:505.

25. Stapleton A, Latham RH, Johnson C, Stamm WE. Post-coital antimicrobial prophylaxis for recurrent urinary tract infection. JAMA 1990;264:703.

26. Pfau A, Sacks T, Engelstein D. Recurrent urinary tract infection in premenopausal women: prophylaxis based on an understanding of the pathogenesis.

J Urol 1983:129:1153.

27. Melekos MD, Asbach HW, Gerharz E, Zarakovitis IE, Weingaertner K, Naber KG. Post-intercourse versus daily ciprofloxacin prophylaxis for recurrent urinary tract infections in premenopausal women. J Urol 1997:157:935-9.

28. Wong ES, McKevitt M, Running K, Counts GW, Turck M, Stamm WE. Management of recurrent urinary tract infections with patient-administered single-dose therapy. Ann Intern Med 1985;102:302-7.

29. Hooton TM, Stamm WE. Management of acute uncomplicated urinary tract infection in adults. Med Clin North Am 1991;75:339-57.
30. Pinson AG, Philbrick JT, Lindbeck GH, Schorling JB. Oral antibiotic therapy for acute pyelonephritis: a methodological review of the literature. J Gen Intern Med 1992;7:544-53.

31. Safrin S, Siegel D, Black D. Pyelonephritis in adult women: inpatient versus outpatient therapy. Am J Med 1988;85:793-8.

32. Stamm WE, McKevitt M, Counts GW. Acute renal infection in women: treatment with trimethoprim-sulfamethoxazole or ampicillin for 2 to 6 weeks. A randomized trial. Ann Intern Med 1987;106:341-5.

33. Harding G, Nicolle L, Wenman W, et al. Randomized comparison of oral ciprofloxacin vs standard parenteral therapy in the treatment of complicated urinary tract infections. Drugs 1993;45(Suppl 3):333-4.

34. Childs SJ, Egan RJ. Bacteriuria and urinary infections in the elderly. Urol Clin North Am 1996:23:43-54.

35. Nicolle LE, Mayhew WJ, Bryan L. Prospective randomized comparison of therapy and no therapy for asymptomatic bacteriuria in institutionalized elderly women. Am J Med 1987;83:27-33.

36. Schaeffer AJ. Infections of the urinary tract. In: Walsh PC, Retik AB, Stamey TA, Vaughan, eds. Campbell's Urology, 6th edn. Philadelphia: WB Saunders Company, 1992.

37. Andriole VT, Patterson TF. Epidemiology, natural history, and management of urinary tract infections in pregnancy. Med Clin North Am 1991;75:359-73.

38. Kass EH. Bacteriuria and pyelonephritis of pregnancy. Arch Intern Med 1960;105;194.

39. Harris RE, Gilstrap LC, Pretty A. Single-dose antimicrobial therapy for asymptomatic bacteriuria during pregnancy. Obstet Gynecol 1982;59:546-9.

40. Hooper DC, Wolfson JS. Fluroquinolone antimicrobial agents. N Engl J Med 1991;324:384.

41. Boscia JA, Abrutyn E, Kaye D. Asymptomatic bacteriuria in elderly persons: treat or do not treat? Ann Intern Med 1987:106:764-6.

42. Zhanel GG, Harding GKM, Guay DRP. Asymptomatic bacteriuria. Which patients should be treated? Arch Intern Med 1990;150:1389-96.

43. Harding GKM, Nicolle LE, Ronald AR, et al. How long should catheter-acquired urinary infection in women be treated? A randomized controlled study. Ann Intern Med 1991:114:713-9.

44. Warren JW, Damrom D, Tenney JH, Hoopes JM, Deforge B, Muncie HL Jr. Fever, bacteremia and death as complications of bacteriuria in women with long term urethral catheters. J Infect Dis 1987;155:1151-8.

45. Meares EM. Prostatitis: review of pharmacokinetics and therapy. Rev Infect Dis 1982;4:475-83.

46. Fowler Jr JE. Prostatitis. In: Adult and Pediatric Urology, 3rd edn. Gillenwater JY, Grayhack JT, Howards SS, Duckett W, eds. St Louis: Mosby, 1996.

47. Wolfson JS, Hooper DC. Fluoroquinolone antimicrobial agents. Clin Microbiol Rev 1989;2:378-424.

48. Lawee D, Csima A. Diabetes-related lower extremity amputations in Ontario: 1987-88 experience. Can J Public Health $1992 ; 83: 298-302$.

49. LoGerfo FW, Coffman JD. Vascular and microvascular disease of the foot in diabetes: Implications for foot care. N Engl J Med 1984;311:1615-9.

50. The Diabetes Control and Complications Trial Research Group. The effect of intensive treatment of diabetes on the development and progression of long-term complications in insulin-dependent diabetes mellitus. N Engl J Med 1993;329:977-86. 
51. Louie TJ, Bartlett JG, Tally FP, Gorbach SL. Aerobic and anaerobic bacteria in diabetic foot ulcers. Ann Intern Med 1976;85:461-3.

52. Caputo GM, Cavanagh PR, Ulbrecht JS, Gibbons GW, Karchmer AW. Assessment and management of foot disease in patients with diabetes. $\mathrm{N}$ Engl J Med 1994;331:854-60.

53. Grayson ML, Gibbons GW, Balogh K, Levin E, Karchmer AW. Probing to bone in infected pedal ulcers: A clinical sign of underlying osteomyelitis in diabetic patients. JAMA 1995;273:721-3.

54. Ziment I, Miller LG, Finegold SM. Nonsporulating anaerobic bacteria in osteomyelitis. Antimicrob Agents Chemother 1968;7:77-85.

55. Lipsky BA, Pecoraro RE, Larson SA, Hanley ME, Ahroni $\mathrm{JH}$. Outpatient management of uncomplicated lower extremity infections in diabetic patients. Arch Intern Med 1990; 150:790-7.

56. Birke JA, Sims DS. Plantar sensory threshold in the ulcerative foot. Lepr Rev 1986;57:261-7.

57. Sosenko JM, Kato M, Soto R, Bild DE. Comparison of quantitative sensory-threshold measures for their association with foot ulceration in diabetic patients.
Diabetes Care 1990;13:1057-61.

58. LoGerfo FW, Gibbons GW, Pomposelli FB, et al. Trends in the care of the diabetic foot: Expanded role of arterial reconstruction. Arch Surg 1992;127:617-20.

59. Gibbons GW, Marcaccio EJ, Burgess AM, et al. Improved quality of diabetic foot care, 1984 vs 1990. Arch Surg 1993; 128:576-81.

60. Eckman MH, Greenfield S, MacKey WC, et al. Foot infections in diabetic patients: Decision and cost effective analysis. JAMA 1995;273:712-20.

61. Louie TJ. Intravenous to oral stepdown antibiotic therapy: Another cost-effective strategy in an era of shrinking health care dollars. Can J Infect Dis 1994;5(Suppl C):45C-50C.

62. Bamberger DM, Daus GP, Gerding DN. Osteomyelitis in the feet of diabetic patients: Long term results, prognostic factors, and role of antimicrobial and surgical therapy. Am J Med 1987;83:653-60.

63. Thompson W, Louie TJ, Brunham RC. Duration of antimicrobial therapy for diabetic foot osteomyelitis. Royal College of Physicians and Surgeons of Canada Annual Meeting. Clin Invest Med 1994;17(Suppl A):4. (Abstr) 


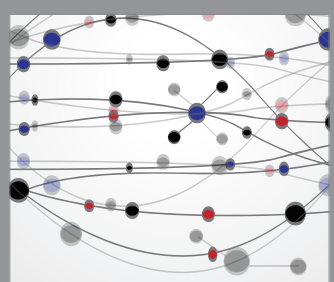

The Scientific World Journal
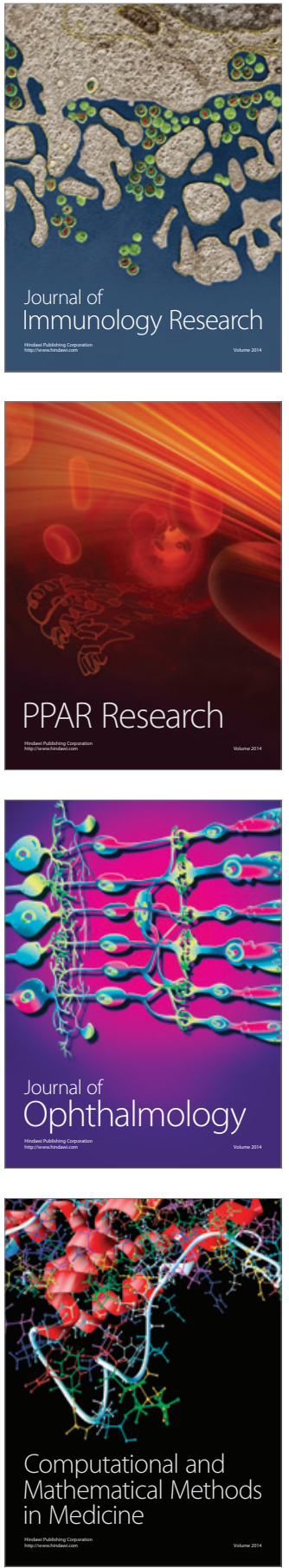

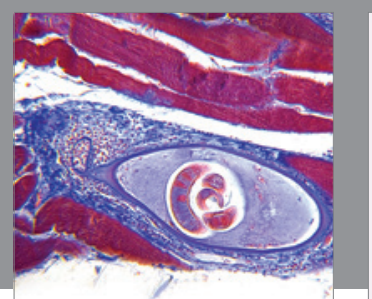

Gastroenterology Research and Practice

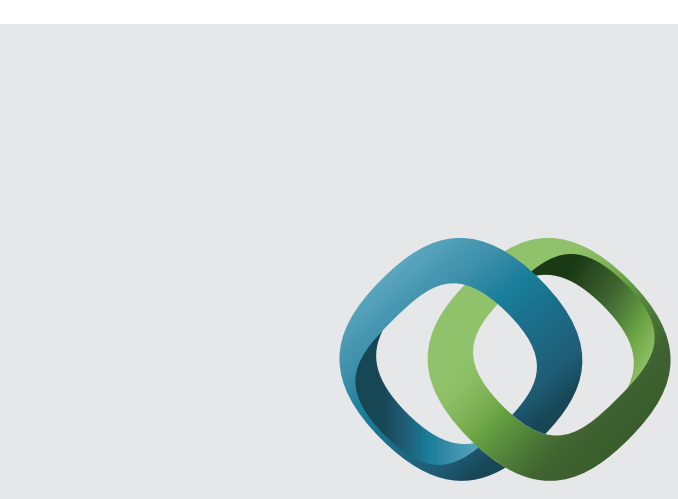

\section{Hindawi}

Submit your manuscripts at

http://www.hindawi.com
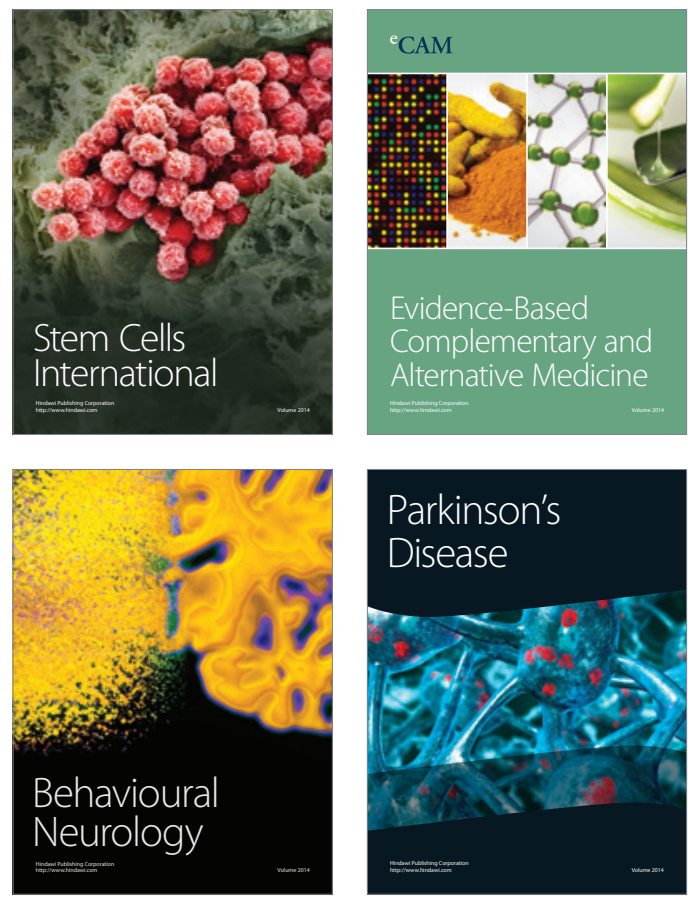
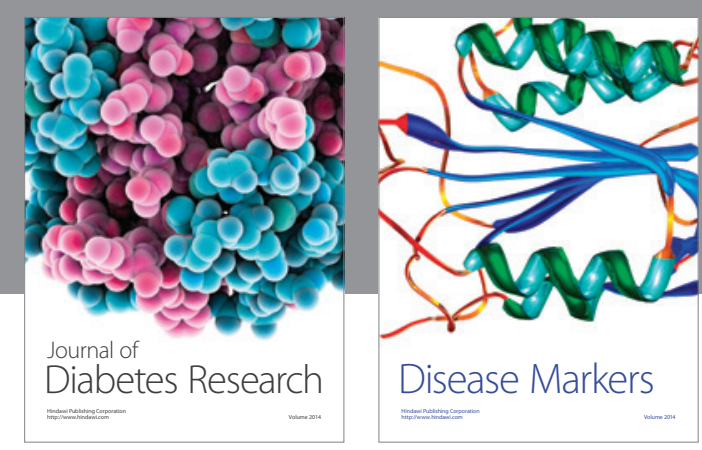

Disease Markers
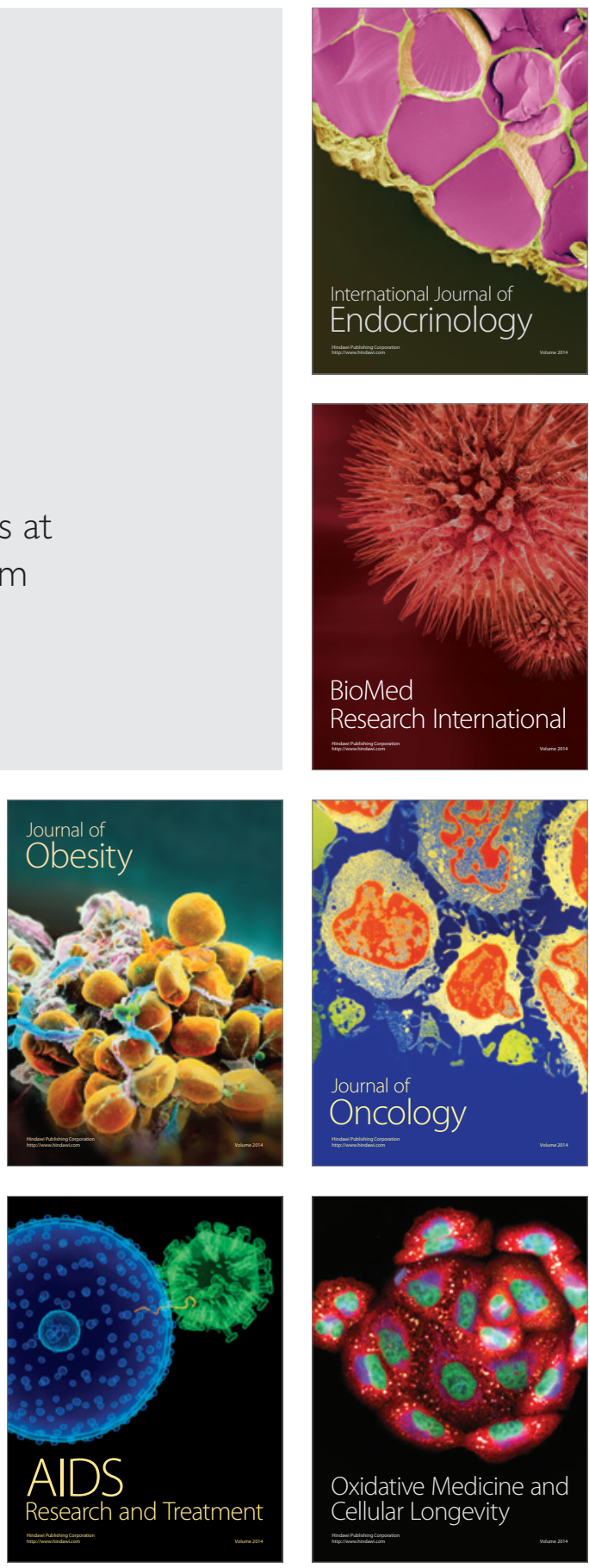